\title{
PRAGMATIC AND COGNITIVE ASPECTS OF ABBREVIATIONS AND ACRONYMS IN LAW DISCOURSE
}

\author{
Natalia Udina \\ Associate professor, RUDN University, the RUSSIAN FEDERATION, udinann@gmail.com
}

\begin{abstract}
Abbreviations have become a peculiar feature of specialized language and communication, carrying out important pragmatic and cognitive functions and revealing specific features of their formation and structure. The global use of abbreviations made linguists and specialists consider this phenomenon in various communicative settings to account for their specific features.
\end{abstract}

Abbreviations have been considered as a productive source of word formation, as lexical units, they have been attributed to words, concepts and linguistics units in general.

Abbreviations came into use since ancient time and are found in all languages. Their main pragmatic functions have been facilitating communication, providing for language economy, coding specific data and others. But their intensified use nowadays often brings about contradictory outcome such as interfering with understanding or processing information.

The use of abbreviations in law has been specific, depending on the type of legal documents or discursive practice. There are multiple special abbreviations intended for clear and concise communication between police officers in emergency cases or keeping some information confidential. The use of various types of abbreviations could be confusing as they can impede communication. Their use in official documents often made necessary to provide comprehensive lists of abbreviations to decipher their meanings.

With growing criticism of unclear or vague legal writing on the one part and intensified cooperation among countries regulated by national and international laws on the other, make the study of abbreviations relevant and will contribute to understanding their functions and significance in accessing specific information and concepts.

Keywords: abbreviations, context, pragmatics, cognitive aspect, law discourse.

\section{INTRODUCTION}

The use of abbreviations has been typical of specialized discourse, but the growing flow of information made the use of abbreviations widespread in all spheres. The computer and Internet mediated communication which is often text-based made abbreviations common even in daily communication (Kelsey, Amant, 2008).

Some specialized fields of activities introduce dictionary of abbreviations intended to facilitate information processing by specialists and scientists, such as Dictionary of abbreviations in linguistics (Jung, 1991), in medicine (Meriam Webster Medical Dictionary), in law (Kavass, 1992) and other domains. Now we can 
witness the growing role of abbreviations in communication and the processes which go along with this development have to be investigated, considering their pragmatic and cognitive aspects.

The use of abbreviations can be traced back to the ancient texts and inscriptions on monuments or objects to denote their purpose. Abbreviations in Latin are often explained by the brevity of lapidary Latin style, usually they were made of first letters of the words with no distinction of number or case. But later the plural form was denoted by double consonants, e.g. $\mathrm{D} \cdot \mathrm{N}$ (dominus noster) changed into plural DD・NN (domini nostri) (Sandys, 2005). These processes could be considered as early signs of lexicalization of abbreviations.

The use of abbreviations in ancient times could be explained by lack of space and imperfect graphic tools to produce texts. Abbreviations or special symbols had been used on pieces of arts or amphorae and pottery to indicate a master, date or place, thus performing important social and historical functions.

The present studies of abbreviations identify the various forms, usually classified as initialisms or alphabetisms, acronyms, shortenings and contractions. Some authors claim that the classification of abbreviation is not comprehensive.

The present interest in abbreviations is often defined by the lack of categorization and typology, as well as the lack of fixed boundaries between various types of abbreviations (Fabijanic, 2014).

In law discourse abbreviations are widely used and found in the texts of laws, documents, opinions, judgments, court cases, etc. The reasons for abbreviations use have been intended to reduce formal clichés or phrases, to avoid repetition of long phrases, which cannot be omitted in the text. The use of abbreviations contributes to concise description of necessary formal information.

The pragmatic and cognitive aspects and various functions of abbreviations are of particular importance as the unprecedented growth of various abbreviations came into use and their role in language development and communication has to be investigated.

\section{THEORETICAL APPROACHES TO ABBREVIATIONS STUDIES IN LAW}

The studies of language of particular discourse require methodology which provides reliable approaches to achieve research goals. Speaking about pragmatic and cognitive aspects of abbreviations in legal discourse we have to see what types of abbreviations are used in law and to specify the particular law discourse. As the notion of law discourse is rather broad we will focus on legal documents which can be related to various spheres of law and dealt with by both law specialists and other participants of legal discourse. The following corpus of legal texts has been analyzed law texts, court judgments and Interpol commission decisions (UK Law un Education, the RF Law on Education, Court judgments, Interpol decisions).

The abbreviation is defined as a shortened from of a word or phrase. The following types of phrase abbreviations are initialisms and acronyms Initialisms and acronym are written in upper case, or if they are fully lexicalized lower case can be used (Kepa, Perry, 2006 ). Initialisms are made of the first letters of words such as the UN (United Nations Organization), the RF (Russian Federation), the letters are pronounced separately. Acronym acquires form made of the first letters or syllables of the words and is spoken as a word, e.g. INTERPOL (International Criminal Police Organization, COVID (corona virus disease), Cybercrime (criminal activities carried out by means of computer/internet). Individual words can be abbreviated: para. (Paragraph), this form can be used in plural 'paras'. Some plural forms of abbreviations could be related to ancient ways of formation, using double letters, like 'pp.' (pages). Some forms of abbreviations involve the use of symbols, such as monetary signs 'P' (Russian ruble), typographical signs (§) etc. Abbreviations used in chat and messaging often take rebus elements (gr8).

The above mentioned forms of abbreviations have been represented unevenly in the texts chosen for analysis, the main function being to avoid repetition of cumbersome words, phrases or terms (Smyth, 2004).

The analysis of abbreviations' functions show their multifunctional character which comes from their forms and various contexts: linguistic and discursive. Functional approaches to language studies cover a wide range of approaches cognitive, cultural, which become more socially oriented (Gotti,2003). Pragmatic aspect of using language units usually takes into account various contexts and deals with ambiguity, implicatures, presupposition and other properties of sentences/utterances. Pragmatics is intended to reveal various aspects which influence the speaker's intentions and choice of language units.

Pragmatics studies tend to become cognitively directed in last decades. The Relevance theory in pragmatics developed by Dan Spereber and Deirdre Wilson in 1995 has become one of the leading approach to current pragmatic studies (Spereber, Wilson, 1995). 
Relevance theory is based on H. Paul Grice's Cooperative principles (1989) and considers communication not only as linguistic expression of meaning, but various non-linguistic means of communication. The Theory of Relevance outlines the cognitive principle of relevance as one of the most important one. The relevance affects the input to the human cognitive system, being positive to the input effects and negative to the input processing efforts. Relevance theory in pragmatics provides psychological insight into utterances producing and understanding (Hall, 2018).

The cognitive principle of relevance deals with not only implicit, but explicit aspects of communication. Cognitive processes include various types of attention and memory, organization, problem solving, executive function. The role of language in cognitive and communication processes is of particular importance.

\section{ABBREVIATION FUNCTIONS ANALYSIS IN LAW CONTEXT}

Communication in law discourse, the content analysis of law discourse and the use of abbreviations in legal communication reveal their specific functions.

The forms of abbreviations used in legal discourse are presented mainly by initialisms, shortenings and acronyms. Considering texts of law on education in the UK and the Russian Federation it was found that in the text of Russian law no abbreviations were used through all its 111 articles. In the references to particular articles, sections or parts these nouns were used in full forms. The main purpose of using no abbreviations in the text of law has been to avoid any possible confusion and emphasize importance of the law. It is one of specific characteristic of official style. In other legislative documents the noun 'statya' (article) is abbreviated to two letters 'st', here the abbreviation seems to perform the most common function of reducing repetition of the same term. The abbreviation FZ (Ф3) - Federalny Zakon (Federal Law) is used in the titles of Federal laws after the law number. This abbreviation serves the distinctive function to differentiate federal and other types of laws.

The similar feature has been characteristic of the text of Law on Education in the UK, with few abbreviations being used, mostly of the similar types. Thus some references to previous documents were in the form of abbreviations, like EA 1996 (Education Act) or FHEA 1992 (Further and Higher Education Act) and very few acronyms ASCLA (Apprenticeship, Skills, Children and Learning Act) and Ofqual (Office of Qualification and Examination Regulation) have been in the text (Education Act, 2011).

The above mentioned abbreviations were used to provide references to the documents or organizations which have been in use previously, amended or abolished.

The following type of legal text, a Court Judgment, makes use of wide range of abbreviations which is due to its specific discourse, language, structure and function in communication. The abbreviations are used to refer to particular laws: the SSFA 1998 (School Standards and Framework Act), the AA 2010 (the Academies Act). The long title could be shortened to one word, e.g. the 'Regulations' for Health Protection (Coronavirus, Restrictions) (England) Regulations (SI 2020/350) and their parts (sections, articles) of the particular laws: 'under s.3 (2)e' (under section), 'para'. (paragraph), 'P.' (part), in this context symbols could be used as abbreviations: 'see at $\S \S 17-21$ '. The function of initialisms, used in the court judgment to refer to previous judgments and legislation they were founded on or to particular parts of the judgment under consideration. Considering specifics of precedent law, the function of abbreviations referring to the particular decision could be defined deictic. The so called discourse deixis provides a reference to backward or forward information in the text, but should not be confused with the anaphora and cataphora (Levinson, 1983).

In UK legal systems the titles of judges and counselors are abbreviated as individual letters or initialisms: $J$ (judge), LJ (Lord Judge), QC (Queen Counselor) (Kerr, 2005). Court judgements could also abbreviate the names of the courts or court divisions 'SCD' (Special Crime Division) and 'organizations 'DET' (Durand Education Trust).

Special knowledge of abbreviation meaning is required to understand particular abbreviations which are widely used in particular field of law and could be used without previous decoding of abbreviated phrase, which could affect understanding of the text by lay people.

In court decisions the common abbreviations for the technical devices could be mentioned in various contexts of violation descriptions or witnesses: 'ANPR' (Automatic Number Plate Recognition) or 'CCTV' (closed-circuit television) and others.

The use of abbreviations in Interpol Decisions of the commission was limited and represents the initialisms for the names of various Interpol departments: NSB (the National Central Bureau of Interpol) or rules - RPD (Rules on the Processing Data). 
Unlike these documents of the Interpol, the abbreviations used by national and local police departments are numerous and often intended for coded information important when dealing with various violations or crimes, such as abbreviations used by the USA police: CCW (Carrying Concealed Weapon) and others.

The use of acronyms in the corpus of analysed texts of laws, court judgments and Interpol commission decisions is less common than initialisms, which could be explained by their pragmatic and cognitive aspects. Acronyms are more complicated in structure and could be less accurate in meaning, so more cognitive load is required to process the information. Though the very name of organization abbreviated as Interpol became well known and often mentioned in the Interpol documents.

\section{CONCLUSION}

The phenomenon of abbreviation in language has been of keen interest in linguistics as they are effective not only in providing concise information, but perform many other functions in specialized discourses, and now are common in communication using electronic devices. Their role is underestimated and the study of pragmatic and cognitive aspects of abbreviations has to reveal their specifics in various communicative contexts.

The analysis of abbreviations in law discourse identified such functions as avoiding repetition of specific terms, providing for concise information, discourse deictic function, stylistic function, distinctive function, coding information function, genre functions. The forms of abbreviations found in a particular sphere of law differ, the use of initialisms is predominant, special knowledge of abbreviated forms is often required to understand their meaning.

Abbreviation process comes into use in many areas of human activity, as information flows are getting intensified the role of abbreviations become more diversified. The pragmatic and cognitive aspects of abbreviations in law discourse promote in-depth study of their discursive functions and communication perspectives.

\section{REFERENCE LIST}

Fabijanic, I. (2014). Dictionary of Abbreviations in Linguistics: Towards Defining Cognitive Aspects as Structural Elements of the Entry.

URL: http://euralex2014.eurac.edu/en/callforpapers/Documents/EURALEX\%202014 gesamt.pdf

Gotti, M. (2003). Specialised discourse: Linguistic Features and changing conventions. Bern: Peter Lang.

Grice, H. Paul (1989): Logic and conversation. William James lectures, Harvard University. In: H. Paul Grice (ed.): Studies in the Way of Words. Cambridge, Mass.

Hall A. (2018) Relevance Theory. In: Liedtke F., Tuchen A. (eds) Handbuch Pragmatik. J.B. Metzler, Stuttgart. URL: https://doi.org/10.1007/978-3-476-04624-6 8

Jung, U.O.H. (1991). The Dictionary of Acronyms and Abbreviation in Applied Linguistics and Language Learning. Vol.1. Peter Lang GmbH, International Verlag Wissenschaften.

Kavass, I.I.(1992). Prince M.M. Ed. World Dictionary of Legal Abbreviations. William S Hein \& Co.

Kelsey, S., Amant, St. K. (2008). Handbook of Researcg on Computer mediated Communication. Volume 1. Hershey, New York. Information Science Reference.

Kepa, K. and Perry, J. (2006) Pragmatics. Zalta E.N. Ed. The Stanford Encyclopedia of Philosophy.

URL: https://plato.stanford.edu/archives/spr2020/entries/pragmatics/

Levinson, St.(1983). Pragmatics. Cambridge University Press, London, New York.

Merriam-Webster Medical Dictionary (2020). URL: https://www.merriam-webster.com/browse/medical

Sandys, E. J. (2005). Ed.. A Companion to Latin Studies. First edition 1910. Cambridge University Press.

Smyth T.R. (2004) Abbreviations and Numbers. In: The Principles of Writing in Psychology. Macmillan Study Skills. Red Globe Press, London.

Sperber, D., Wilson, D. (1995). Relevance: Communication and Cognition. Oxford.

Law on Education, the RF (2012). URL: http://www.consultant.ru/document/cons doc LAW 140174 
Proceedings of INTCESS 2021 8th International Conference on Education and Education of Social Sciences 18-19 January, 2021

Law on Education, the UK (2011). URL : https://www.legislation.gov.uk/ukpga/2011/21/contents/enacted

Court Judgments, the UK. URL: https://www.judiciary.uk/wp-content/uploads/2020/12/r-durand-educationaltrust-v-sofs-for-education-judgment-1.pdf

Court Judgment, the UK. URL: https://www.judiciary.uk/wp-content/uploads/2020/11/Redston-v-DPPjudgment.pdf

Interpol Resources. Decisions of commission URL: https://www.interpol.int/Resources/Documents\#Legal

BAILII resources, the UK. URL: https://www.bailii.org/ 